\title{
Urban Infestation Patterns of Argentine Ants, Linepithema humile, in Los Angeles
}

\author{
Smadar Gilboa, ${ }^{1}$ John H. Klotz, ${ }^{2}$ and Peter Nonacs ${ }^{1}$ \\ ${ }^{1}$ Department of Ecology and Evolutionary Biology, 621 Young Dr. S., University of California, Los Angeles, CA 90095, USA \\ ${ }^{2}$ Department of Entomology, University of California, Riverside, CA 92521, USA
}

Correspondence should be addressed to Peter Nonacs, pnonacs@biology.ucla.edu

Received 21 February 2012; Revised 21 May 2012; Accepted 31 May 2012

Academic Editor: Brian Forschler

Copyright ( $) 2012$ Smadar Gilboa et al. This is an open access article distributed under the Creative Commons Attribution License, which permits unrestricted use, distribution, and reproduction in any medium, provided the original work is properly cited.

\begin{abstract}
Infestations of buildings by Argentine ants, Linepithema humile (Mayr), were monitored on the campus of the University of California, Los Angeles. Foraging ant activity peaked during the hotter months of the year. The mean monthly maximum temperature, but not rainfall, positively correlated with indoor infestation frequency. Neither garden size nor the predominant groundcover vegetation correlated with the number of foraging ants at baits within gardens. Although the number of foraging ants outside a building varied over 40 -fold, ant density in gardens did not predict the likelihood of infestation within the building. Also, the type of vegetative groundcover employed did not predict infestation frequency. There was, however, a significant negative relationship between the size of the garden outside of a building and the number of infestations. Given the large foraging area of L. humile workers, buildings next to small gardens may be infested simply because they lie within the "normal" foraging area of a colony. The best predictor of which rooms were infested within buildings was the presence of a water source. Thus providing water for ant colonies outside and away from buildings may be one method of integrated pest management to reduce the proclivity of ants to infest structures.
\end{abstract}

\section{Introduction}

Argentine ants (Linepithema humile (Mayr)) are a worldwide invasive exotic pest [1-3]. In urban areas that have a Mediterranean type climate they often invade dwellings and are one of the most consistently reported pest species [3-9]. Although L. humile tends to form high-density monocultures outdoors [10-14], it is not ubiquitous in its infestation patterns. Environmental factors such as mean yearly rainfall and minimum winter temperatures can broadly predict whether L. humile colonies can survive, but local abundances will be better predicted by idiosyncratic features such as human disturbance, native ant species presence, or irrigation regimes [15]. This variance suggests that there are identifiable, local factors that can also predict the likelihood of an infestation in buildings. One such factor could be features within rooms (e.g., food, water, and potential nest sites) that attract ants. A second variable could be the landscaping practices around buildings and their influence on ant activity and density $[5,9,16]$.
The University of California, Los Angeles (UCLA) provides an urban setting in which infestations and their indoor and outdoor correlates can be measured. The ant fauna on the grounds is effectively limited to L. humile and buildings vary in how often ants invade them. Through the auspices of the university, access is available to the grounds and many of the buildings. Thus, investigative reports of ant infestations can be matched relative to landscape parameters on the outside of buildings and to the room characteristics at the site of the infestation. Identifying existing patterns can lead to insights regarding best landscaping design practices to minimize L. humile infestations.

\section{Methods}

2.1. Study Site. This study was conducted on the campus of UCLA. During the study period, the main campus had 94 buildings and structures, of which a number had chronic infestations of $L$. humile for multiple years. The campus landscaping is relatively uniform consisting primarily of 
combinations of grass, ivy, shrubs, and several species of trees (mostly sweet gums, sycamores, eucalyptus, and several species of pine). The landscape is interspersed with solidly paved walkways that create gardens of various sizes adjacent to buildings (Figure 1). These paved areas all have heavy human foot traffic. Although it is likely that the ants at UCLA are a single unicolonial [3] population interconnected by trails and the movements of foragers, the pavement dividers create areas where ants cannot nest and are found only when travelling. Hence, gardens are the only islands of high-density nests from which infestations can radiate to adjacent buildings. Argentine ants can be found in every gardened area on the campus, and no other ant species are evident (Gilboa and Nonacs, pers. obs.). All gardens were regularly irrigated and soil moisture levels did not differ significantly across sites. For analyses, the predominant vegetation defining given gardens were combined into three inclusive categories: grass, low groundcover other than grass (e.g., ivy), and bushes or hedges. A significant food source for L. humile is honeydew from tended insects $[3,4]$. We did not measure insect densities (other than ants) across vegetation types. Therefore, any differences across vegetation categories may be due to differences that are physical, biological, or both.

2.2. Tracking Infestation Patterns. We obtained the records of complaint calls to UCLA's central Facilities Management about ant infestations for the period of March 2002-August 2003. Across this time period, infestations were reported in 28 buildings on campus. After receiving a report, descriptive details of the infestation were collected at the site. This included the following: (1) the room location; (2) noting within the room whether water, food, or plants (i.e., potential L. humile nest sites) were present; (3) measuring the size of the closest garden outside the building to the room of the infestation. The intensity of the infestation (i.e., number of ants) was not recorded as UCLA facilities personnel had usually treated the ants prior to our arrival, by placing commercial bait traps inside the infested rooms. Access to some sites of infestation was either not available or the exact location was not specified in the complaint. In total, data from 42 rooms in 15 buildings were collected. For 14 of the buildings (Figure 1) the size (in $\mathrm{m}^{2}$, using precise ARC-GIS maps available for the UCLA campus) of the closest garden to the infested rooms and the predominant vegetation type were calculated and recorded. For the remaining building, the infestation occurred over $100 \mathrm{~m}$ from the nearest garden. All buildings had numerous human occupants and were all either classroom, office, laboratory, administration, or some combination thereof. All appeared structurally sound and were regularly maintained by facility personnel. None were under construction or major renovation at the time of the study. There were no obvious differences across buildings in terms of potential entry points for ants.

Buildings that did not report infestations could not be assumed to be ant-free. Lack of complaints could also be due to higher tolerance for infestations of only a few ants by the building's occupants, or problems being handled at the site rather than being reported to central facilities. Furthermore, tolerance for ants appeared to vary across buildings (e.g., Business School occupants seemed more willing to complain about ants than occupants of Life Sciences buildings). Such human behavioral differences, however, do not affect the time series analyses because buildings act as their own controls. It is assumed that the tolerance level towards ants, per se, in a given room, in a given building is the same relative to the immediate weather conditions, the time of year, and the nature of the nearest outside garden. Therefore, changes in the numbers of complaints about ants reflect changes in ant and not human behavior.

The activity levels of ants in the gardens closest to infestations were measured by 10 buildings (of the 14 reported above), 2 of which were measured in both summer and winter months. Measurements took place in AugustSeptember (2003) and January-March (2004). Ant activity was estimated by the rate of removal of $50 \%$ solutions of sugar water from 9-10 vials placed in each garden under clay pots (to minimize evaporative loss). Vials initially contained approximately $22 \mathrm{~g}$ of solution. Control vials which did not allow ant access measured evaporative loss. The amount of solution taken was measured every day, and the vials were never completely emptied over this time period. Based on an estimate that an L. humile worker can take $0.3 \mathrm{mg}$ per visit, the total number of ant visits from the amount of liquid removed in a day were calculated (see $[6,17]$ for details of methods). This method is recommended as accurate and the least time-consuming for monitoring comparative levels of Argentine ant activity [17]. Because the collected data were often not normally distributed, nonparametric statistics were mostly employed. Statview was used for all statistical analyses.

Weather data (e.g., daily temperature and rainfall) were used from an on-campus weather station operated by the National Oceanic and Atmospheric Agency.

\section{Results}

3.1. Factors Affecting Ant Activity. Measured mean ant activity was higher in outside gardens in hotter months (mean maximum temperature $>21^{\circ} \mathrm{C}$ ) than in colder months (7234 versus 1936; Mann-Whitney $U$ test, $Z=-2.038, P=$ 0.0415 ), and in drier months (cumulative rainfall $<1 \mathrm{~cm}$ ) than wetter months (11126 versus 2639; Mann-Whitney $U$ test, $Z=-2.208, \quad P=0.0272)$. However, neither the size of the garden (range: 116-1123 $\mathrm{m}^{2}$ ) nor the predominant type of vegetation (bushes, grass, or ivy) had a significant effect on the number of visits to baits (Table 1). This suggests that whatever physical or biological characteristics differed across the vegetation types, they did not significantly affect L. humile activity patterns. These data were also subdivided according to whether a given month was hot or cold and dry or wet to identify specific effects of temperature and rainfall. In none of these subsets of data was there a significant relationship.

3.2. Factors Affecting Frequency of Infestation. Infestation rates, as number of calls complaining about ants, showed three peaks: in the summer months of both 2002 and 2003 


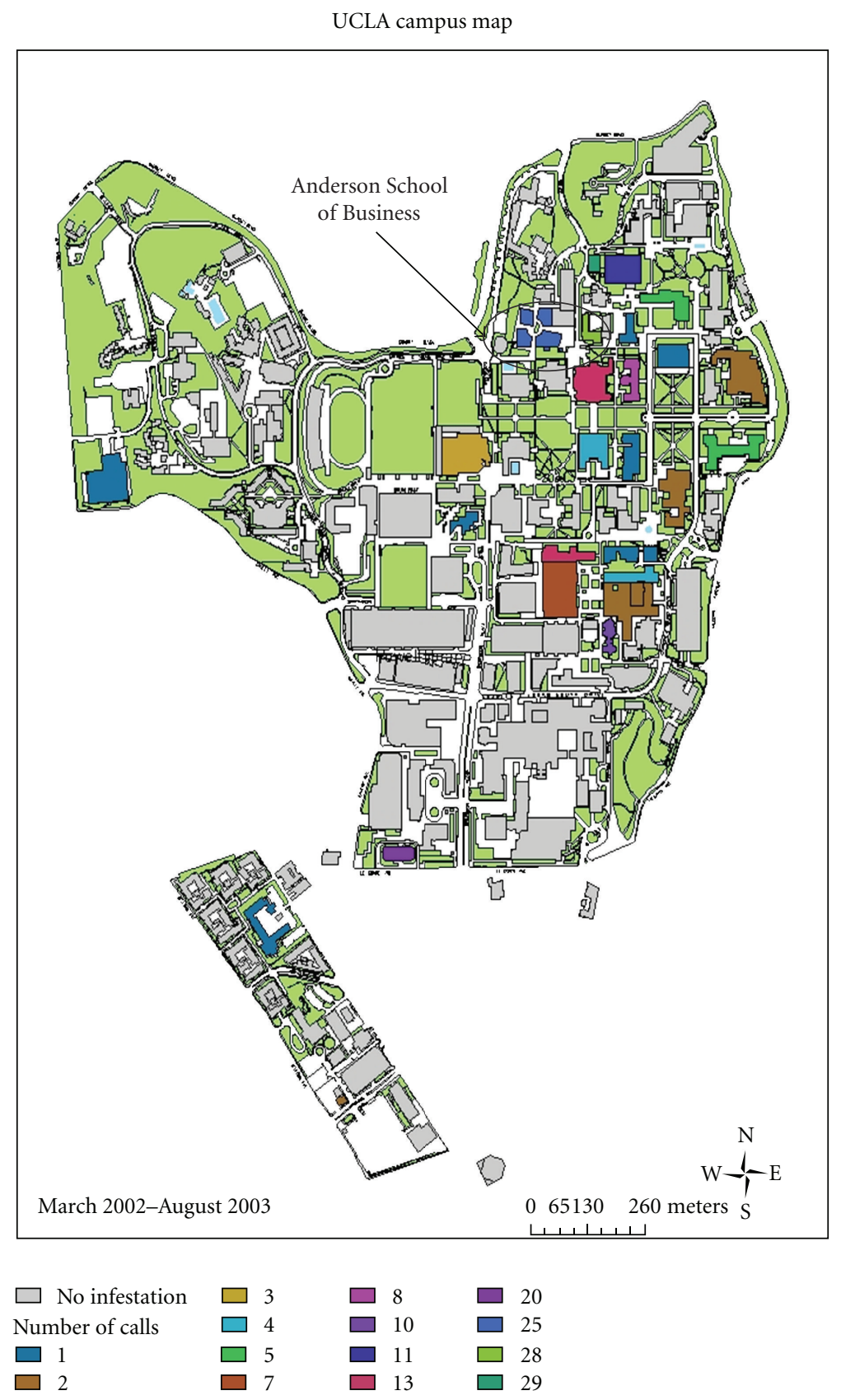

FIGURE 1: Map of UCLA Linepithema humile infestations in 2002-03. The Anderson School of Business is a complex of 4 structures, but only one of them reported all the infestations.

and in Jan/Feb of 2003 (Figure 2). In between these times there were relatively few ant infestations. Calls significantly increased with mean monthly maximum temperature $(y=$ $\left.-46.1+2.6 x ; \mathrm{df}=1.16 ; R^{2}=0.486 ; P=0.0013\right)$, but not in response to monthly rainfall $(y=10.73-0.14 x ; \mathrm{df}=1.16$; $R^{2}=0.004$; NS) or number of days per month with measureable rainfall $\left(y=12.19-0.76 x ; \mathrm{df}=1.16 ; R^{2}=0.024\right.$; NS). Note that January of 2003 was much drier and hotter than normal (i.e., at the time, it was the warmest January on record for UCLA).

Neither ant density in gardens (assumed to correlate to number of visits to baits, range: $358-15684$ sugar water loads removed) nor garden groundcover type, under any condition of monthly temperature or rainfall, were significant predictors of infestations in adjacent buildings (Table 1). Across all months, however, infestation frequency correlated significantly negatively with garden size (Table 1 ). Indeed, a small isolated garden in the midst of the business school complex (Figure 1) seemed the likely source for the many complaints, and ant trails entering the one infested building were directly observed upon inspection (S. Gilboa, per. obs.). These infestation data were also subdivided by mean monthly temperature and cumulative rainfall. In all cases, the same trend was exhibited: infestations were more likely next 
to smaller gardens. The effect, however, was more strongly influenced by rainfall than by temperature (i.e., a statistically significant relationship is present only in wet months).

3.3. Factors Affecting Room Infestation. The main predictor of infestation for particular rooms was the presence of water. In the 42 infested rooms, 35 (74.4\%) had either water sources (e.g., sinks, toilets, faucets, or standing water), potted plants, or a food source. Of these 35,34 had a water source, 17 had plants, and 18 had food. Ten of the rooms had only a water source. One room had only a food source, and no rooms were infested that had only plants. Anecdotally, the occupants of the rooms often reported ants being primarily attracted to water and then mass recruiting if they also found food. The observed infestation pattern associating with water is unlikely to simply reflect a random sampling of rooms by ants. Most of the rooms in the infested buildings were either classrooms, meeting and seminar rooms, or offices (i.e., far fewer than $75 \%$ of the rooms in these UCLA buildings have a significant source of accessible water for ants).

\section{Discussion}

Argentine ant activity on the UCLA campus is similar to that reported elsewhere [18-20]: infestations are at a minimum from March through June which correlates with lowest points of worker numbers [21], worker activity thereafter peaks in the summer, and infestation intensity has a summer and a winter peak (Figure 2). These results differ from Gordon et al. [19] in finding that infestations positively correlate to temperature but are not predicted by rainfall. Northern California has both colder winters and heavier winter rains. Thus the higher incidence of winter infestations may be due to ants seeking warmer and drier nest sites. Interestingly, the one peak in infestation observed in our winter data correlated with a record-breaking January heat wave.

The strongest predictor of where infestations occur in buildings is the presence of a water source (although food and potential nesting sites may influence the number of invading ants and the likelihood of repeated infestations). Several other aspects of our data and findings by others support the hypothesis that water-seeking behavior is a prime factor for why L. humile enters buildings. In our study, the greatest number of infested buildings and complaint calls occurred during hotter and drier months when water-stress is more likely to be an issue. Several ecological studies have also found that soil moisture and water availability have the strongest effect on the distribution of L. humile nests and the species success as an invasive $[8,13,20-25]$. If forced to choose, $L$. humile will prefer nesting in areas of optimal humidity rather than be near food sources $[23,24]$. Other factors, such as vegetation, appear to play indirect roles through their positive effects on soil moisture. A second study on the UCLA campus found that L. humile presence within structures can be significantly reduced by placement of water on the outside of those structures [26].

The data show no effect of local densities of foraging ants in gardens on infestation rates, despite a 40 -fold difference

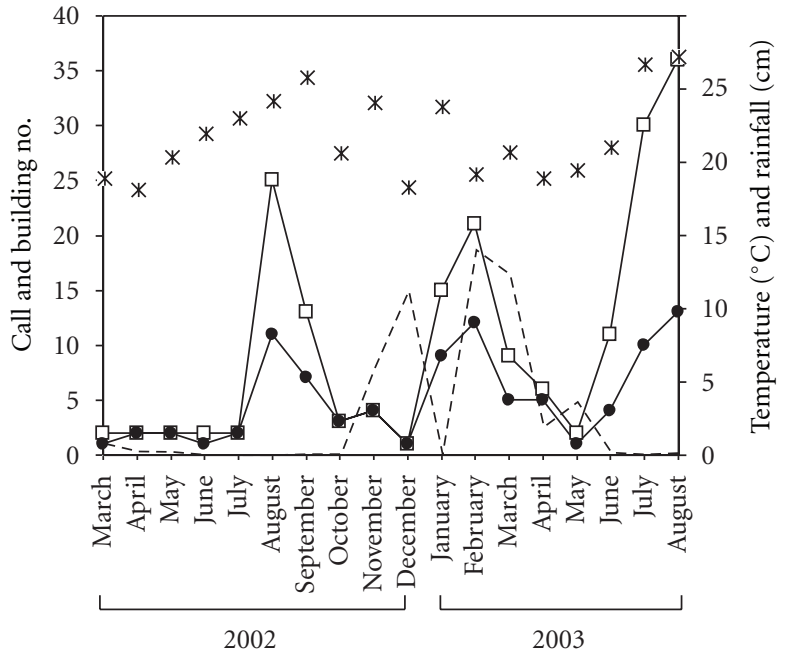

FIGURE 2: Month to month record of infestations and climate data at UCLA. Lines with open squares are the number of total calls; lines with closed circles are the number of buildings infested. The crosses are the mean maximum temperature for the month, and the dashed line is the cumulative monthly rainfall (both from the UCLA station of the National Environmental Satellite, Data, and Information Service).

in local ant activity. This is particularly interesting because it implies that the increase in summer infestations cannot be accounted for by the significantly greater numbers or activity levels of ants in particular gardens. One caveat to the results may be, however, that all our measured densities including the lowest are indicative of a large local population of ants that are available to infest buildings. This is a typical pattern in L. humile where local densities of foragers tend to be high and not correlated to soil dryness [12, 14, 18, 20, 25]. There was also no significant effect of plant species across gardens in terms of either affecting ant densities or likelihood of infestation. It might be that L. humile are insensitive to differences in UCLA plant communities because they receive relatively similar watering regimes. Whether or not the differing plant communities provided different amounts of food for L. humile, such as varying densities of honeydewproviding insects was unknown. However, to any extent that such differences existed, they did not significantly affect infestation patterns.

There was a significant effect of garden size, where surprisingly smaller gardens tended to be associated with increased likelihood of infestation. A potential explanation for this correlation may be that smaller gardens have less food (e.g., fewer homopterans, in total, to tend) and water to maintain the high density of ants. Given the large foraging range that L. humile colonies can exhibit [3], infestations may be the result of "normal" Argentine ant foraging ranges. The small garden effect appears to be particularly evident in wetter months, where reduced food availability might stimulate enlarging the foraged areas.

The attraction that Argentine ants have for suitably moist habitat suggests manipulating water availability can be useful for integrated pest management in urban situations. 
TABle 1: Summary statistics using Spearman rank correlations ( $Z$-values) and Kruskal-Wallis tests $(H$ values). For the Kruskal-Wallis tests $b, g$, and $i$ refer to number of gardens with predominant groundcover of bushes, grass or ivy, respectively.

\begin{tabular}{|c|c|c|c|}
\hline Garden size and ant density & $Z$-value & $P$ value & $n$ \\
\hline All months & -0.377 & NS & 12 \\
\hline Hot months $\left(>21^{\circ} \mathrm{C}\right)$ & 0.252 & NS & 8 \\
\hline Cold months $\left(<21^{\circ} \mathrm{C}\right)$ & -0.693 & NS & 4 \\
\hline Wet months $(>1 \mathrm{~cm})$ & -0.898 & NS & 8 \\
\hline Dry months $(<1 \mathrm{~cm})$ & 1.386 & NS & 4 \\
\hline Garden type and ant density & $H$ value & $P$ value & $b, g, i$ \\
\hline All months & 0.526 & NS & $3,3,6$ \\
\hline Hot months $\left(>21^{\circ} \mathrm{C}\right)$ & 0.717 & NS & $1,2,5$ \\
\hline Cold months $\left(<21^{\circ} \mathrm{C}\right)$ & 0.300 & NS & $2,1,1$ \\
\hline Wet months $(>1 \mathrm{~cm})$ & 0.125 & NS & $2,2,4$ \\
\hline Dry months $(<1 \mathrm{~cm})$ & 2.700 & NS & $1,1,2$ \\
\hline Infestations and ant density & $Z$-value & $P$ value & $n$ \\
\hline Hot months $\left(>21^{\circ} \mathrm{C}\right)$ & -0.598 & NS & 8 \\
\hline Cold months $\left(<21^{\circ} \mathrm{C}\right)$ & 1.126 & NS & 4 \\
\hline Wet months $(>1 \mathrm{~cm})$ & 1.606 & NS & 8 \\
\hline Dry months $(<1 \mathrm{~cm})$ & -0.693 & NS & 4 \\
\hline Infestations and garden type & $H$ value & $P$ value & $b, g, i$ \\
\hline All months & 0.606 & NS & $3,4,7$ \\
\hline Hot, dry months $\left(>21^{\circ} \mathrm{C},<1 \mathrm{~cm}\right)$ & 0.366 & NS & $3,4,7$ \\
\hline Cold, dry months $\left(<21^{\circ} \mathrm{C},<1 \mathrm{~cm}\right)$ & 0.008 & NS & $3,4,7$ \\
\hline Hot, wet months $\left(>21^{\circ} \mathrm{C},>1 \mathrm{~cm}\right)$ & 0.733 & NS & $3,4,7$ \\
\hline Cold, wet months $\left(<21^{\circ} \mathrm{C},<1 \mathrm{~cm}\right)$ & 1.168 & NS & $3,4,7$ \\
\hline Infestations and garden size & $Z$-value & $P$ value & $n$ \\
\hline All months & -2.104 & 0.0354 & 12 \\
\hline Hot, dry months $\left(>21^{\circ} \mathrm{C},<1 \mathrm{~cm}\right)$ & -1.853 & 0.0638 & 12 \\
\hline Cold, dry months $\left(<21^{\circ} \mathrm{C},<1 \mathrm{~cm}\right)$ & -1.525 & NS & 12 \\
\hline Hot, wet months $\left(>21^{\circ} \mathrm{C},>1 \mathrm{~cm}\right)$ & -2.104 & 0.0354 & 12 \\
\hline Cold, wet months $\left(<21^{\circ} \mathrm{C},<1 \mathrm{~cm}\right)$ & -2.299 & 0.0215 & 12 \\
\hline
\end{tabular}

Clearly within buildings access to water can be controlled [7]. Outside of buildings, planting drought-resistant, xeric gardens may keep larger nests away from structures [24]. If these are not options, then the reverse is also possible; provide easily accessible water to the ants particularly during times of hot, dry weather. If water is available on the outside and away from structures, this may keep ants from searching inside buildings. For example, using less than a liter of water per day, Enzmann et al. [26] significantly shifted the movement patterns of $L$. humile populations from the inside of structures to the outside. Such manipulations may be particularly useful if ants are present in gardens smaller than their normal foraging range. In conclusion, because trails of L. humile form connected networks $[22,27]$, this may present the opportunity to minimize ant problems through moving those networks with simple landscaping solutions.

\section{Acknowledgments}

The authors thank L. Lowe and J. Powazek from UCLA Facilities Management. This work was supported by UCIPM Grant 02XA013 from the USDA. Brittany Enzmann and
Jeff Thomas helped with the placement and collection of ant baits.

\section{References}

[1] A. V. Suarez, D. A. Holway, and T. J. Case, "Patterns of spread in biological invasions dominated by long-distance jump dispersal: insights from argentine ants," Proceedings of the National Academy of Sciences of the United States of America, vol. 98, no. 3, pp. 1095-1100, 2001.

[2] A. M. Soeprono and M. K. Rust, "Strategies for controlling argentine ants (Hymenoptera: Formicidae)," Sociobiology, vol. 44, no. 3, pp. 669-682, 2004.

[3] J. Silverman and R. J. Brightwell, "The argentine ant: challenges in managing an invasive unicolonial pest," Annual Review of Entomology, vol. 53, pp. 231-252, 2008.

[4] M. K. Rust and R. L. Knight, "Controlling Argentine ants in urban situations," in Applied Myrmecology, R. K. Vander Meer, K. Jaffe, and A. Cedeno, Eds., pp. 663-670, Westview Press, 1990.

[5] J. H. Klotz, L. Greenberg, H. H. Shorey, and D. F. Williams, "Alternative control strategies for ants around homes," Journal of Agricultural and Urban Entomology, vol. 14, no. 3, pp. 249257, 1997. 
[6] S. J. Vega and M. K. Rust, "The Argentine ant-a significant invasive species in agricultural, urban and natural environments," Sociobiology, vol. 37, no. 1, pp. 3-25, 2000.

[7] D. A. Reierson, M. K. Rust, and J. H. Klotz, "There's safety in numbers," Pest Control, vol. 69, pp. 50-52, 2001.

[8] D. A. Holway, A. V. Suarez, and T. J. Case, "Role of abiotic factors in governing susceptibility to invasion: a test with argentine ants," Ecology, vol. 83, no. 6, pp. 1610-1619, 2002.

[9] J. H. Klotz, L. Hansen, R. Pospischil, and M. Rust, Urban ants of North America and Europe, Cornell University Press, Ithaca, NY, USA, 2008.

[10] P. S. Ward, "Distribution of the introduced Argentine ant (Iridomyrmex humilis) in natural habitats of the lower Sacramento Valley and its effects on the indigenous ant fauna, Hilgardia, vol. 55, no. 2, pp. 1-16, 1987.

[11] D. A. Holway, "Distribution of the Argentine ant (Linepithema humile) in Northern California," Conservation Biology, vol. 9, pp. 1634-1637, 1995.

[12] K. G. Human and D. M. Gordon, "Exploitation and interference competition between the invasive Argentine ant, Linepithema humile, and native ant species," Oecologia, vol. 105, no. 3, pp. 405-412, 1996.

[13] D. A. Holwa, "Factors governing rate of invasion: a natural experiment using Argentine ants," Oecologia, vol. 115, no. 12, pp. 206-212, 1998.

[14] D. A. Holway, "Competitive mechanisms underlying the displacement of native ants by the invasive argentine ant," Ecology, vol. 80, no. 1, pp. 238-251, 1999.

[15] S. B. Menke, R. N. Fisher, W. Jetz, and D. A. Holway, "Biotic and abiotic controls of argentine ant invasion success at local and landscape scales," Ecology, vol. 88, no. 12, pp. 3164-3173, 2007.

[16] H. E. Meissner and J. Silverman, "Effect of aromatic cedar mulch on argentine ant (Hymenoptera: Formicidae) foraging activity and nest establishment," Journal of Economic Entomology, vol. 96, no. 3, pp. 850-855, 2003.

[17] P. Alder and J. Silverman, "A comparison of monitoring methods used to detect changes in Argentine ant (Hymenoptera: Formicidae) populations," Journal of Agricultural and Urban Entomology, vol. 21, no. 3, pp. 142-149, 2004.

[18] M. K. Rust, D. A. Reierson, E. Paine, and L. J. Blum, "Seasonal activity and bait preferences of the Argentine ant (Hymenoptera: Formicidae)," Journal of Agricultural and Urban Entomology, vol. 17, no. 4, pp. 201-212, 2000.

[19] D. M. Gordon, L. Moses, M. Falkovitz-Halpern, and E. H. Wong, "Effect of weather on infestation of buildings by the invasive Argentine ant, Linepithema humile (Hymenoptera: Formicidae)," American Midland Naturalist, vol. 146, no. 2, pp. 321-328, 2001.

[20] L. A. DiGirolamo and L. R. Fox, "The influence of abiotic factors and temporal variation on local invasion patterns of the Argentine ant (Linepithema humile)," Biological Invasions, vol. 8, no. 2, pp. 125-135, 2006.

[21] G. P. Markin, "Seasonal life cycle of the Argentine ant, Iridomyrmex humilis, (Hymenoptera: Formicidae) in Southern California," Annals of the Entomological Society of America, vol. 63, pp. 1238-1242, 1970.

[22] K. G. Human, S. Weiss, A. Weiss, B. Sandler, and D. M. Gordon, "Effects of abiotic factors on the distribution and activity of the invasive Argentine ant (Hymenoptera: Formicidae)," Environmental Entomology, vol. 27, no. 4, pp. 822-833, 1998.

[23] N. E. Heller and D. M. Gordon, "Seasonal spatial dynamics and causes of nest movement in colonies of the invasive
Argentine ant (Linepithema humile)," Ecological Entomology, vol. 31, no. 5, pp. 499-510, 2006.

[24] S. B. Menke and D. A. Holway, "Abiotic factors control invasion by Argentine ants at the community scale," Journal of Animal Ecology, vol. 75, no. 2, pp. 368-376, 2006.

[25] D. T. Bolger, "Spatial and temporal variation in the Argentine ant edge effect: implications for the mechanism of edge limitation," Biological Conservation, vol. 136, no. 2, pp. 295305, 2007.

[26] B. E. Enzmann, K. M. Kapheim, T. B. Wang, and P. Nonacs, "Giving them what they want: manipulating Argentine ant activity patterns with water," Journal of Applied Entomology. In press.

[27] N. E. Heller, K. K. Ingram, and D. M. Gordon, "Nest connectivity and colony structure in unicolonial Argentine ants," Insectes Sociaux, vol. 55, no. 4, pp. 397-403, 2008. 

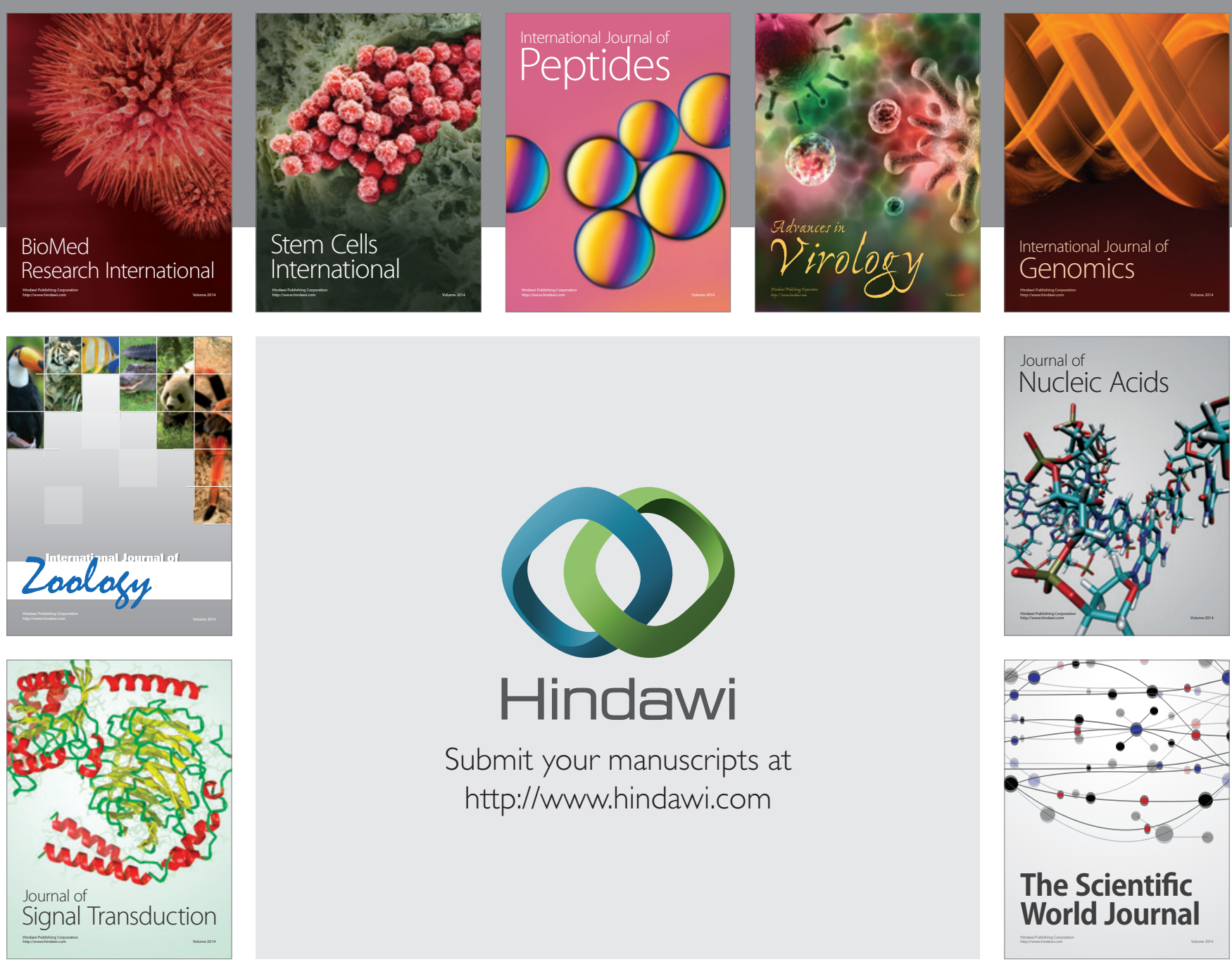

Submit your manuscripts at

http://www.hindawi.com
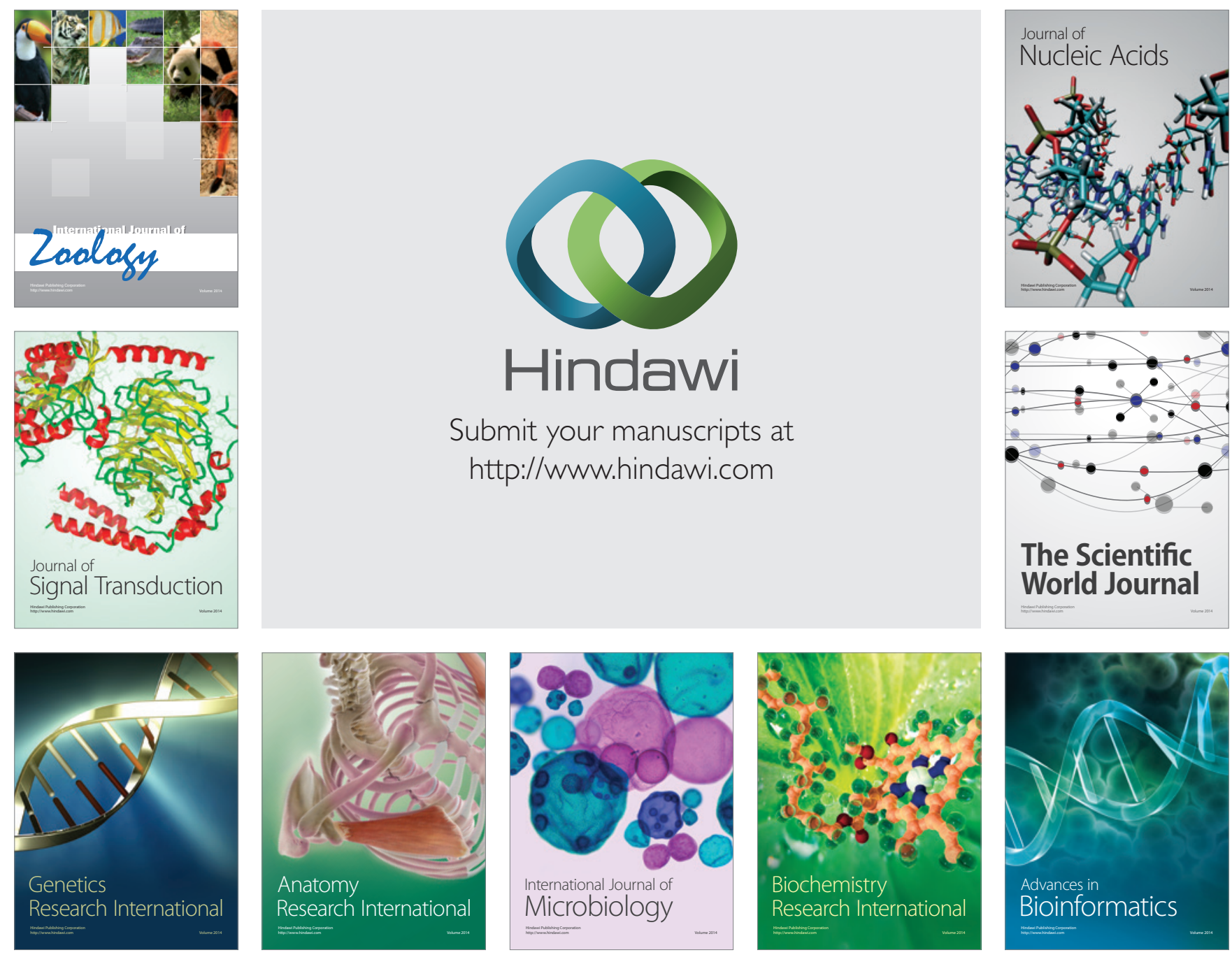

The Scientific World Journal
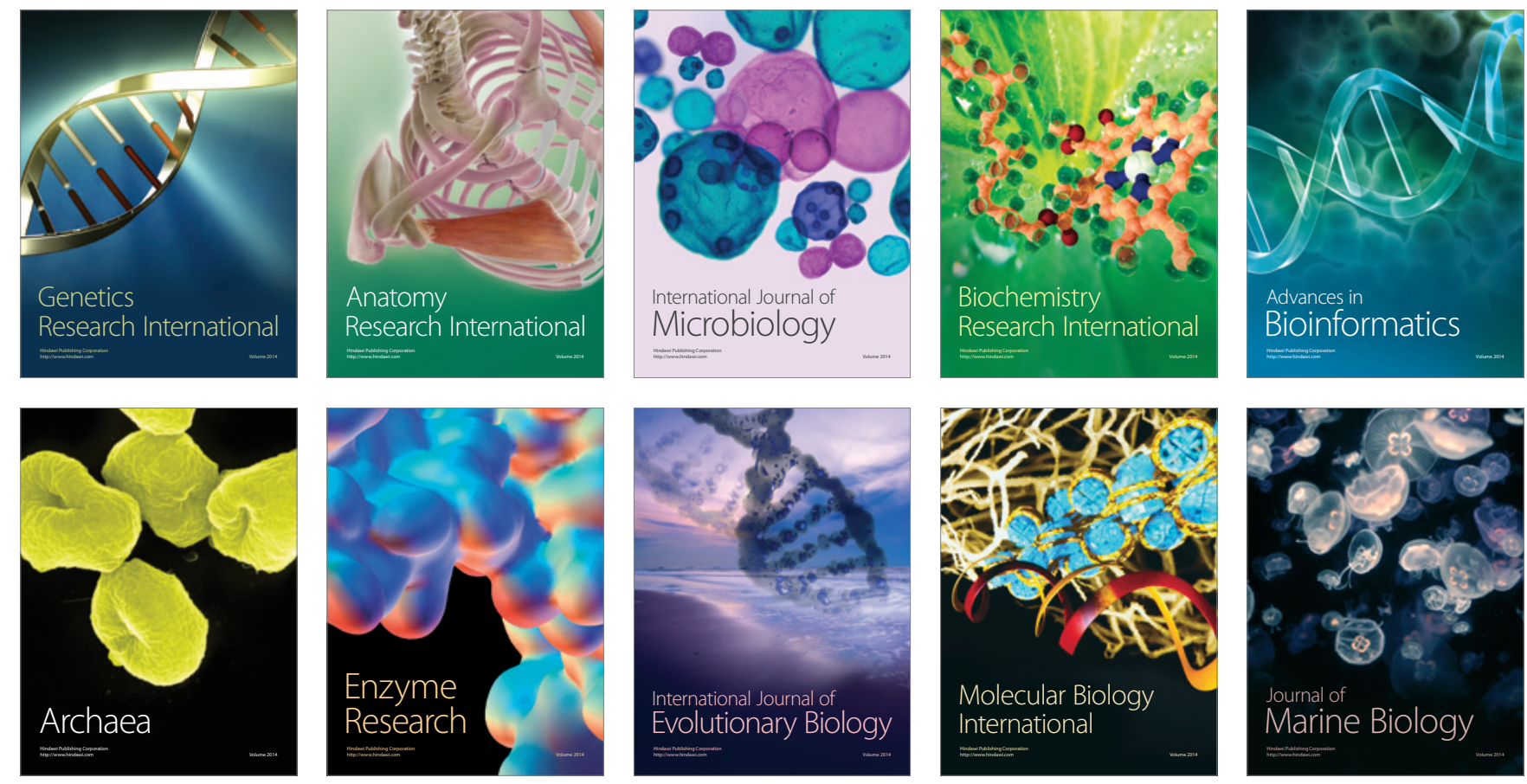